\title{
Do Dentistry and physical education students know the importance of mouthguard usage in sports practice?
}

\author{
Os alunos da Odontologia e Educação Física conhecem a importância \\ do uso de protetores bucais na prática desportiva?
}

\author{
Priscilla Maria Lima do NASCIMENTO' ${ }^{1}$ iD 0000-0003-1066-4663 \\ Danielle Ferreira SOBRAL-SOUZA² iD 0000-0001-6147-964X \\ Paulo Cardoso LINS-FILHO ${ }^{1}$ iD 0000-0002-1809-7168 \\ Rafael Antonio de Oliveira RIBEIRO3 ${ }^{3}$ (D) 0000-0001-8100-3294 \\ Hilcia Mezzalira TEIXEIRA4 ${ }^{4}$ 0000-0001-8556-2018 \\ Alexandre Batista do NASCIMENTO4 ID 0000-0001-5546-0424
}

\section{ABSTRACT}

Objective: The purpose of the present study was to evaluate the knowledge of Dentistry and Physical Education students on mouthguard usage in sports practice. Methods: A form containing questions that demonstrated participants' knowledge about the use of mouthguards was applied. Inclusion criteria were: individuals older than 18 years who were attending Dentistry or Physical Education courses from the sixth period and who agreed to participate in the study, and the exclusion criteria for dentistry students were: attended the discipline of Dental Materials II of UFPE and already participated in internships in schools or academies for the participants of the Physical Education course. Results: it was possible to observe that $97 \%$ of the interviewees know what a mouthguard is, but none of the participants would be able to indicate a specific type of mouthguard to sportsmen. Conclusion: It was possible to conclude that a large number of the interviewees know what a mouthguard is, but not enough to indicate which is the safest protector.

Indexing Terms: Dentistry. Mouth protectors. Physical education and training. Wounds and Injuries

\section{RESUMO}

Objetivo: Avaliar o conhecimento dos alunos do curso de Odontologia e Educação Física sobre os protetores bucais nos desportos. Métodos: Aplicação de formulário avaliando conhecimento dos participantes sobre o uso de protetores bucais. Os critérios de inclusão

$\boldsymbol{\nabla v \nabla}$

1 Universidade Federal de Pernambuco. Av. Prof. Moraes Rego, 1235, 50670-901, Cidade Universitária, Recife, PE, Brasil. Correspondência para / Correspondence to: PML NASCIMENTO. E-mail: <priscillanascimento91@yahoo.com.br>.

2 Universidade Estadual de Campinas, Programa de Pós-Graduação em Clínica Odontológica - área de concentração Dentística. Piracicaba, SP, Brasil.

3 Universidade Estadual Júlio de Mesquita Filho, Programa de Pós-Graduação em Reabilitação Oral - Área de Prótese. Araraquara, SP, Brasil.

${ }^{4}$ Universidade Federal de Pernambuco, Departamento de Prótese e Cirurgia Buco Facial. Recife, PE, Brasil.

$\boldsymbol{\nabla} \boldsymbol{\nabla} \boldsymbol{V}$

How to cite this article

Nascimento PML, Sobral-Souza DF, Lins-Filho PC, Ribeiro RAO, Teixeira HM, Nascimento AB. Do Dentistry and physical education students know the importance of mouthguard usage in sports practice?. RGO, Rev Gaúch Odontol. 2019;67:e20190038. http://dx.doi.org/10.1590/1981-8 6372019000383668 
foram: indivíduos maiores de 18 anos que estivessem cursando os cursos de Odontologia ou Educação Física a partir do sexto período e que concordassem em participar da pesquisa, já os critérios de exclusão para os alunos do curso de Odontologia foram: não ter cursado a disciplina de Materiais Dentários II da UFPE e já ter participado de estágios em escolas ou academias no caso dos participantes do curso de Educação Física. Resultados: foi possível observar que 97\% dos entrevistados sabem o que é um protetor bucal, porém, nenhum dos participantes saberiam indicar um tipo especifico de protetor bucal aos desportistas. Conclusão: que uma grande parcela dos entrevistados conhece o que é um protetor bucal, porém, não o suficiente para poder indicar qual o protetor mais seguro.

Termos de indexação: Odontologia. Protetores bucais. Educação Física e treinamento. Ferimentos e lesões. Trauma.

\section{INTRODUCION}

Shocks and injuries commonly occur during sports. Contact sports are the most susceptible to injury $[1,2]$. In this way, sports activities with greater contact are more likely to cause secondary damages. However, these damages can be remedied by the use of sports protectors [3].

In the field of protective sports equipment, the innovations did not satisfactorily include the orofacial region, allowing a significant number of individuals affected by injuries in this region during sports practice [4]. Such injuries can generate aesthetic, psychological and financial impacts related to both functional and aesthetic rehabilitation as well as the need to move away from professional sports activities, which is why educational and preventive measures are necessary [5-8].

Sports Dentistry is one of the branches of dentistry that seeks to improve the performance of athletes by preventing injuries and promoting health, as well as adding other professionals for multidisciplinary action [1,9-11].

The use of mouth guards can prevent physical damage to oral structures, drastically reduce treatment costs, need for corrective surgery, aesthetic and psychological treatments $[12,13]$. The practice of using these devices is already widespread in more developed countries, and their use is a requirement in sports practice $[6,7,10]$.

Many papers discuss the importance of using mouth guards $[3,7,14-16]$. However, only one article brought the importance of knowledge about this preventive measure among students in Dentistry and Physical Education [13].

Thus, the objective of this study was to evaluate the knowledge of undergraduate students of the Dentistry and Physical Education courses of the Federal University of Pernambuco - UFPE - Campus - Recife on the buccal protectors in sports and discuss the role of the Dentist in the care of sportsmen.

\section{METHODS}

The research was initiated after approval by the Research Ethics Committee involving human beings of the Federal University of Pernambuco (CAAE: 53811916.2.0000.5208). All the participants of the research signed the Term of Free and Informed Consent, authorizing the disclosure of the obtained data.

A cross-sectional study randomly selected 50 students from the Physical Education course and another 50 from Dentistry, observing minimum criteria such as: respondents older than 18 years attending the sixth period, excluding those who did not study the Dental Materials II, in the case of students of the Dentistry course, and Physical Education students who participated in internships in schools or academies.

A questionnaire was applied by a single calibrated researcher, constructed and adapted from the work of Sizo et al. [14] to assess the representativeness of the sample, of the order of $40 \%$ of the total number of students eligible to participate the level of knowledge that undergraduate students of Dentistry and Physical Education present about the mouth guards.

The form consisted of 6 easy-to-understand questions aimed at assessing the interviewees' level of knowledge about the indications and use of oral protection devices, besides the injuries that can be prevented with their use.

Data were collected at the center of each course and individually so as not to cause any external interference in the responses. After completing the form, a brief elucidation was made on the subject and reinforced the importance of the two areas acting so that both help in the prevention and reduction of major damages.

The responses were tabulated in MS Excel spreadsheets and exported for processing and data analysis using the SPSS-Statistical Package for the Social Sciences, version 22, with significance level for all parameters 
analyzed, set at $5 \%$. The statistical analysis of the data obtained regarding the questionnaire responses was submitted to both descriptive and date cross tabulation analysis.

\section{RESULTS}

100 forms were answered, so all answers are considered valid.

Table 1. Response to the questionnaire of the students of the courses of Dentistry and Physical Education about the knowledge of each one.

\begin{tabular}{lcccc}
\hline & All students & All students & Students of Dentristy & Students of Physical Education \\
\hline & $\begin{array}{l}\text { Do you know what a } \\
\text { mouth guard is? }\end{array}$ & $\begin{array}{l}\text { Do you know any type of } \\
\text { mouth guards? }\end{array}$ & $\begin{array}{l}\text { Do you know any type of } \\
\text { mouth guards? }\end{array}$ & $\begin{array}{l}\text { Do you know any type of mouth } \\
\text { guards? }\end{array}$ \\
\hline $\begin{array}{l}\text { Affirmative answers } \\
\text { to questionnaire } \\
\text { questions }\end{array}$ & $97 / 100(97 \%)$ & $n(\%)$ & & $n(\%)$ \\
\hline
\end{tabular}

Table 1 shows the response of both courses on the knowledge that each individual presented when asked about: knowing what a protector is and knowing their types. It is observed that $97 \%$ of respondents indicated knowing what is mouth guards, however, $49 \%$ of respondents stated that they did not know any type, or brand, of mouth guards. Among the respondents who do not know something of a mouth guards, $55.1 \%$ are students of Physical Education, a fact, relatively surprising because of the contact that these students have with various types of sports.

According to Table 2, $80 \%$ of the respondents who declared that they knew the mouth guards stated that they knew the mouth protector through the media,

Table 2. Questionnaire response of students in dentistry and physical education courses on how they learned about the use of protectors - general assessment and by course.

\begin{tabular}{|c|c|c|c|}
\hline & FOR cursE & DENTISTRY & PHYSICAL EDUCACION \\
\hline Variable & $\begin{array}{l}\text { Valid percentage } \\
\qquad(n \%)\end{array}$ & $\begin{array}{l}\text { Valid percentage } \\
\qquad(n \%)\end{array}$ & $\begin{array}{l}\text { Valid percentage } \\
\qquad(n \%)\end{array}$ \\
\hline Media & $40,6 / 100(47 \%)$ & $32,6 \backslash 100(33 \%)$ & $48,0 \backslash 100(48 \%)$ \\
\hline Graduation & $15,6 \backslash 100(16 \%)$ & $26,1 \backslash 100(26 \%)$ & $6,0 \backslash 100(6 \%)$ \\
\hline P.E.P & 7, 3\100 (7\%) & $2,2 \backslash 100(2 \%)$ & $12,0 \backslash 100(12 \%)$ \\
\hline D.P. & $8,3 \backslash 100(8 \%)$ & $10,9 \backslash 100(11 \%)$ & $6,0 \backslash 100(6 \%)$ \\
\hline Graduation and media & 7, 3\100 (7\%) & $15,2 \backslash 100(15 \%)$ & \\
\hline Media and P.E.P* & 1, $0 \backslash 100(1 \%)$ & $2,2 \backslash 100(2 \%)$ & \\
\hline Media and D.P* & $1 \backslash 100(1 \%)$ & $2,2 \backslash 100(2 \%)$ & \\
\hline Media, P.E.P and D.P & $4,2 \backslash 100(4 \%)$ & $2,21100(2 \%)$ & $6,0 \backslash 100(6 \%)$ \\
\hline Others & $14,6 \backslash 100(15 \%)$ & $6,5 \backslash 100(6 \%)$ & $22,0 \backslash 100(6 \%)$ \\
\hline Total & 100,0 & 50,0 & 50,0 \\
\hline
\end{tabular}

Note: M - Media. P.E.P - Physical Education professional. D.P - Dentistry professional. 
by information of the professional graduation of Physical Education and dental professional, cumulatively.

In order to observe the extent of knowledge regarding the applicability of the mouth guards, Table 3 shows the distribution of answers to the following questions: What type of damage can the protector prevent? which sports have the highest indication of use (analysis of the response of both courses and separately), and if the theme has relevance to be discussed since graduation. It is observed that fractures correspond to a higher frequency of responses, $43 \%$, and fights are the most indicated sport as more likely to occur this type of damage. $95 \%$ of the respondents understand that this topic has relevance for graduation.

Table 3 also shows a cross-analysis in which a comparison is made between the classes of the respondents (students of Physical Education or Dentistry) and the positioning on the importance of this subject being approached in the undergraduate program.

It is observed that $98 \%$ and $92 \%$ of the students of Dentistry and Physical Education, respectively, consider this important subject to be approached in the graduation. The table shows that considering the two groups there is a convergence of $95 \%$ to accept the importance of the subject.

Table 3. Response to the questionnaire of students in dentistry and physical education courses when questioned about what kind of damage the mouth guard can avoid, for which type of sport it is most appropriate and if the theme is relevant to be discussed during graduation?

\begin{tabular}{|c|c|}
\hline Variable & Frequency \\
\hline Trauma & $11 / 100(11 \%)$ \\
\hline Fractures & $31 / 100(31 \%)$ \\
\hline Soft tiusses injuries & $10 / 100(10 \%)$ \\
\hline Total & 100 \\
\hline Variable & Frequency \\
\hline Fights & $67 / 100(67 \%)$ \\
\hline Contact Sports & $32 / 100(32 \%)$ \\
\hline No answer & $1 \backslash 100(1 \%)$ \\
\hline Total & 100 \\
\hline Variable & Frequency \\
\hline No & $5 / 100(5 \%)$ \\
\hline Yes & $95 / 100(95 \%)$ \\
\hline Total & 100 \\
\hline
\end{tabular}

\section{DISCUSSION}

The work can show the differences of knowledge that exist about the use and indications of the buccal protector, in the courses that were the target of the study.

The increase in the number of individuals practicing sports activities, whether for recreational or competitive purposes, increases the susceptibility to trauma and accidents related to such practices, increasing the incidence of traumatic injuries [3,6,15-17].

In the present study, it was possible to observe that $97 \%$ of the participants stated that they know what the protective device is called the mouth guards. However, when gauging the number of individuals who know at least one type of mouth guards this value reduces to $0 \%$. That is, despite knowing the existence of the devices, future professionals do not know how to indicate or recognize the types of protectors.

The equipment in particular exerts the function of damping and redistribution of shock forces during impact and can be classified into protector: universal, prefabricated and individual $[3,18,19]$.

The universal protector has a unique pattern, that is, it does not fit uniformly in users, it has low cost, easy access and can be found in stores of sporting goods [1921]. And this type of protector has poor performance, discomfort during use, not properly accommodating the dental arch, besides disrupting phonation breathing, and swallowing of the user [3,11,19-21].

On the other hand, prefabricated, thermoplastic or "warm and bite" type protectors have a better adaptation when compared to universal ones. However, its use is by immersing it in hot water, where the heat of the water causes its original shape to be momentarily undone and when placed in the mouth, the device takes on a new configuration which is a copy of the format of the dental arch of its user [7,11,19-21].

This type of device provides the false sense of protection since, when the protector returns to its natural state, there is no guarantee that there is an equal distribution of all material around the entire dental arch. In addition, it can cause burns to the soft tissues by being inserted still warm in the oral cavity $[7,11,19-21]$.

The most suitable for athletes is the buccal protector of the individual type, which is made by the Dentist, this device is the most cost-effective to the sportsman since 
it requires the impression of the buccal characteristics of its user and is precisely because it has a better adaptation $[7,11,20]$.

A better fit is synonymous with better force dissipation during the impact shock, ie the forces that affect the mouth are damped and redistributed equally so that the oral tissues may not suffer as much. This device is also recognized for not interfering with speech, swallowing or breathing, making its use safer and more comfortable $[3,7,20]$. Another factor that contributes to the occurrence of harmful episodes is the insufficient knowledge of the fans of the sport and the unpreparedness of the professionals who work alongside them [13].

When asked about how the mouth guards knew, a significant number of participants stated that it was approximately $40 \%$ in the media, followed by a graduation of $16 \%$ and a professional in the area of Dentistry $7 \%$ and Physical Education 8\%.

In evaluating these results, taking into account the course, we will have in both media as the most far reaching information channel with approximately $48 \%$ and $33 \%$ respectively for physical education and dentistry. As for the Dentistry course, it stands out with about $26 \%$ of participants who said they received the knowledge through the academy.

As can be seen in table 2, when asked if they had received information from a professional in the area, $07 \%$ of the interviewees of the Dentistry course sought information from the Dental Surgeons and 08\% from the physical educators. In contrast, the Physical Education course showed lower values for those who sought information from the Dental Surgeons, only $6 \%$ and $12 \%$ for those who sought professionals from the same area.

For Freitas et al. (2008) 7 Physical Education professionals have a lack of knowledge even of what to do after an oral trauma, reflecting a delicate situation for the physical educator since they deal with the eminence of accidents in the oral region daily [13].

Such problems can be prevented with simple measures such as the use of mouth guards. In addition, it is important to note that the impact caused by the trauma affects not only the teeth but also affects the soft tissues, causing swelling, lacerations and concussions $[4,11,12]$.

Therefore, it is imperative that professionals who work closely with athletes be made aware of the importance of safety practices7. Individuals who are sporting practitioners are likely to crash, however, accidents do not occur only in competitions, but may also occur during preparatory practices prior to competitions [22].

That is why educational actions on the importance of prevention in relation to facial traumas represent the primary level of attention and can be developed in a multidisciplinary and interdisciplinary context7 [23].

Damage to the oral structures is favored in the modalities in which there is greater contact between their competitors or in which there is the eminence of shock with the surface of the game. Damage to the oral region is also more common because it is a more pronounced region, making the face an easier target to reach [24].

For those interviewed, the mouth guard is a device that can help reduce secondary damage such as fractures and trauma, with $32 \%$ and $11 \%$, respectively, of valid responses. Interviewees also believe that the greatest indication of mouth wash is for those who practice fights, following the most contact sports, and this represented $67 \%$ and $32 \%$, respectively.

Practitioners who practice direct contact (boxing, MMA, Muay Thai) and semidireto (soccer, volleyball) are the ones that are most indicated for the use of oral devices. Mainly because they are mixed confrontation activities, they present the possibility of colliding with the ground, environment structures and sports equipment both in training moments and in competitions $[2,22]$.

In the permanent dentition, dental crown fracture, dislocation and avulsion are the most common incidents, while in the deciduous dentition the most common episodes are luxation, intrusion and avulsion of the dental element [25].

In this study there was a significant portion of individuals who believe that the use of the mouth guard can avoid trauma and fractures, this represented about $46 \%$ of the responses. In addition, it is important to note that the impact caused by the trauma affects not only the teeth but also affects the soft tissues, causing swelling, lacerations and concussions $[4,11,12]$.

In addition to the trauma, the presence of oral disorders such as: tooth loss, periodontal diseases, TMJ disorders, malocclusion, mouth breathing, caries are important factors that can significantly affect the performance of athletes, causing a decrease in performance or even even the distance of the athlete from the training and competitions [26-30]. 
We can also observe that most of the students interviewed, 95\%, believe that this topic is important and should be addressed in the courses.

\section{CONCLUSION}

A large proportion of those interviewed know what a mouthguard is, but not enough to indicate which is the best and safest.

The Physical Education course showed to know more about mouth guards, but having the media as the main source of information. On the other hand, the students of the Dentistry course showed a more restricted knowledge, but with a scientific basis.

Both courses are critical with respect to the relevant role and appropriate use of the specific type of mouth guard in the prevention of sports injuries.

\section{Collaborators}

PML NASCIMENTO, research contribution, formulation and application of questionnaires, data collect, writing of the manuscript; reading, correcting and submitting manuscript's final version. DF SOBRAL-SOUZA, research contribution, questionnaires formulation; data tabulation; writing of the manuscript; reading, correcting and approving manuscript's final version. PC LINSFILHO, research contribution, data tabulation; writing of the manuscript; reading, correcting and approving manuscript's final version. RAO RIBEIRO, research contribution, data tabulation; writing of the manuscript; reading, correcting and approving manuscript's final version. AB NASCIMENTO, intellectual contribution to the writing of the manuscript co-advisor, statistical analysis, reading, correction and approval of manuscript's final version. HM TEIXEIRA, intellectual contribution and critical review of the writing and content of the manuscript; advisor, reading, correcting and approving manuscript's final version.

\section{REFERENCES}

1. Padilha ACL. Trabalho de conclusão de curso. Florianópoles; 2012.

2. Mann L, Kleinpaul JF, Teixeira CS, Mota CB. Modalidades esportivas: impacto, lesões e a força de reação do solo. Rev da Educ Física/UEM. 2010;21(3):553-62. doi: 10.4025/ reveducfis.v21i3.6667.

3. Gomes IA, Cordeiro MG, Costa LS, Rudys RJ, Firoozmand LM. Importância do uso do protetor bucal na prevenção de traumas dentais durante a prática esportiva - artigo de revisão. Rev Pesq Saúde. 2014;15(2):30,4-8.
4. Barberini AF, Caldeira CL. Incidência de injúrias orofaciais e utilização de protetores bucais em diversos esportes de contato. Rev Odontol UNICID. 2002;14(1):7-14.

5. Lima DLF. Odontologia esportiva: o cirugião-dentista no cuidado do esportista. São Paulo: Santos; 2013.

6. Costa SDS, Alencar DD, Maia C, Costa IS, Fidelis RT. Odontologia desportiva: melhor performance com a atuação do dentista na prática da atividade física. Col Pesq Educ Física. 2015;14:131-8.

7. Freitas DA, Freitas VA, Antunes SLNO, Crispim RR. Avaliação do conhecimento de acadêmicos de Educação Física sobre avulsão/reimplante dentário e a importância do uso de protetor bucal durante atividades físicas. Rev Bras Cir Cabeça Pescoço. 2008;37(4):215-218. https://doi-org.ez238. periodicos.capes.gov.br/10.1111/iej.13039.

8. Piccininni P, Clough A, Padilha R, Piccininni G. Dental and orofacial injuries. Clin Sports Med. 2017;36(2):369-405. doi: 10.1016/j.csm.2016.12.001.

9. Reinhel AF, Scherma AP, Peralta FS, Palma ICR. Saúde bucal e performance física de atletas. ClipeOdonto - UNITAU. 2015;7(1):45-56.

10. Ferrari $\mathrm{CH}$, Medeiros JMF. Dental trauma and level of information: mouth guards use in different contact sports. Dent Traumatol. 2002;18:144-7. https://doi.org/10.1034/j. 1600-9657.2002.00017.x.

11. Gould TE, Piiland SG, Caswell SV, Mills S, Ferrara M. National athletic trainners' association position statement: preventing and managing sport-related dental an oral injuries. J Athl Train. 2016;51(10):821-39. https://doi.org/10.4085/1062-6 050-51.8.01.

12. Cavalcanti, AL, Santos FG dos, Peixoto LR, Gonzaga AKG, Dias CHS, Xavier AFC. Ocorrência de Injúrias Orofaciais em Praticantes de Esportes de Luta. Pesqui Bras Odontopediatria Clin Integr. 2012;12(2):223-8. https://doi.org/10.4034/PBOCI. 2012.122.11

13. Lages FS, Rivera CP, Araújo DCE, Oliveira DWD. Protetor bucal para esportistas: relato de caso clínico. 2014;24(2):32-6. https://doi.org/10.15600/2238-1236/fol.v24n2p32-36

14. Sizo SR, Silva ES, Rocha MPC, Klautau EB. Avaliação do conhecimento em Odontologia e Educação Física acerca dos protetores bucais. Rev Bras Med do Esporte. 2009;15(4):2826. https://doi.org/10.1590/\$1517-86922009000500010

15. Bastos RS, Vieira EMM, Simões CAD, Sales PSHC, Caldana $\mathrm{ML}$, Lauris JRP, et al. Odontologia desportiva: proposta de um protocolo de atenção à saúde bucal do atleta. RGO, Rev Gaúch Odontol. 2013;61(supl.0):461-8.

16. Sepet E, Aren G, Onur OD, Erdem AP, Kuru S, Tolgay CG, et al. Knowledge of sports participants about dental emergency procedures and the use of mouthguards. Dent Traumatol. 2014;30(5):391-5 https://doi.org/10.111/edit12105

17. Lima LF, Neto CRM. Atenção ao trauma bucal: cotidiano e percepções de atletas do futebol. Rev Odontol Bras Cent. 2015;24(69):54-6.

18. Santiago E, Simões R, Soares D, Pereira JA, Caldas T. Protetor bucal " Custom-Made": indicações, confecção e características essenciais. Arq Med. 2008;22(1):25-33. 
19. Leone CCLD, Barros IRCN, Salles AG, Antunes LAA, Antunes LS. O uso do protetor bucal nas artes marciais: consciência e atitude. Rev Bras Med do Esporte. 2014;20(6):451-5. http:// dx.doi.org/10.1590/1517-86922014200602096.

20. Patrick DG, Noort RV, Found M. Scale of protection and the various types of sports mouthguard. $\mathrm{Br} J$ Sport Med. 2005;39:278-82. http://dx.doi.org/10.1136/bjsm.2004.012 658

21. Saxena $V$, Tiwari $U$, Singh A, Jain M, Goud S. Dental trauma and mouthguard awareness and use among contact and noncontact athletes in central India. J Oral Sci. 2014;56(4):239-43. https://doi.org/10.2334/josnusd.56.239

22. Drum SN, Swisher AM, Buchanan CA, Donath L. Effects of a custom bite-aligning mouthguard on performance in college football players. J Strength Cond Res. 2016;30(5):1409-15. http://dx.doi.org/10.1519/JSC.0000000000001235

23. Cremonez J, Abreu DG. Protetores bucais e seu impacto no condicionamento físico de atletas de futebol. Mouth Protectors and Its Impact on the Physical of Football Athletes. Rev Bras Ciências da Saúde. 2009;(20):39-45. https://doi. org/10.13037/rbcs.vol7n20.318
24. Costa SDS. Odontologia desportiva na luta pelo reconhecimento. Rev Odontol da Univ Cid São Paulo. 2009;21(2):152-68. https://doi.org/10.26843/ro_unicid.v21i2.452

25. Souza JGS, Soares LA, Souza TCS, Pereira AR, Souza AGS. Traumatismos faciais decorrentes da prática esportiva. Rev Bras Cir Cabeça Pescoço. 2013;42(1):53-7.

26. Silveira EG, Araújo SM, Schmitt BHE, Farias MMAG, Campos L, Caregnato M. Conhecimento e atitudes dos odontopediatras do Estado de Santa Catarina acerca de mecanismos de prevenção de traumatismos bucais relacionados a esportes. Rev Odontol da UNESP. 2009;38(6): 341-6.

27. Vanz MP. Alteração do desempenho esportivo associado a causas bucais. Odonto Sci. 2014;78-81.

28. Lima DLF. Odontologia esportiva e interdisciplinaridade. Col Pesq Ed Física. 2009;8(5):193-8. http://dx.doi.org/10.15 90/1517-869220172302168921

29. Antunez MEM, Reis YB. O binômio esporte-odontologia. Adolescência \& Saúde. 2010;7(1):37-9.

Received on: 26/9/2018 Final version resubmitted on: 12/11/2018 Approved on: 12/12/2019 